\title{
Contamination of Anesthesia Circuits by Pathogens
}

\author{
Luiza Alves de Castro Arai ${ }^{1}$, Ricardo Bentes Azevedo ${ }^{2}$
}

Summary: Arai LAC, Azevedo RB - Contamination of Anesthesia Circuits by Pathogens.

Background and objectives: Evaluation of contamination of anesthesia circuits by collecting 56 culture samples from the circular system; previously reprocessed tracheas by disinfection with $1 \%$ hypochlorite or $2 \%$ glutaraldehyde after being washed in non-sterile water and soap and dried by using compressed air and stored in surgical grade paper; and from other places of the non-reprocessed respiratory circuit, before anesthetic procedures.

Methods: Samples from the inspiratory and expiratory branches of the tracheas, canister, soda-lime, and collector jar (drain) through swab in Stuart medium and streaked in Agar blood, Mac Conkey, and Sabouraud growth media.

Results: The level of contamination with fungus and bacteria in the inspiratory and expiratory branches of tracheas reached up to $39.3 \%$ in some sites; in some cases, more than one microorganism was present, $75 \%$ fungal and $25 \%$ bacterial contamination. Cultures were positive for Candida sp., Dermatophytus sp., Penicillium sp., Aspergillus sp., Staphylococcus aureus, Staphylococcus saprophyticus, and Staphylococcus epidermidis. Contamination was observed in $25 \%$ of the canisters with growth of Candida sp., Penicillium sp., Dermatophytus sp., Aspergillus sp., and Fusarium sp. In the collector jar, a contamination rate of $36 \%$ was observed with growth of Candida sp., Dermatophytus sp., S. saprophyticus and Acinetobacter baumannii. Microorganisms did not grow in soda-lime cultures.

Conclusions: In all sites investigated except for soda-lime growth of microorganisms was observed with the possibility of cross infection.

Keywords: Equipment Contamination; Anesthesia, Closed-Circuit; Ventilators, Mechanical; Cross Infection.

[Rev Bras Anestesiol 2011;61(1): 50-59] CElsevier Editora Ltda.

\section{INTRODUCTION}

Soda-lime is an integral part of the anesthesiologist daily practice ${ }^{1,2}$. It absorbs carbon dioxide in the respiratory circuit of the anesthesia equipment, allowing the use of low flow of fresh gases to reduce anesthetic consumption, maintain the body temperature of the patient, airways humidity, and avoid pollution of the operating room ${ }^{3}$. Due to lower consumption of gases and anesthetics, it is an economic ally of the hospital, besides maintaining the humidity of inhaled air, avoiding the harmful effects of dry gases, such as drying, inflammation, and loss of ciliary movement, it decreases flow, reducing pulmonary complacency ${ }^{4}$. Absorption of carbon dioxide represents an exothermic chemical reaction. In the closed circuit, water and heat from the reaction contribute for humidification and warming of the mixture. Besides water from the chemical reaction, water also comes from the loss of liquid from the expiratory phase, which accumulates in the expiratory branch of the respiratory circuit, in the canister, and throughout the circuit therefore creating an ideal culture medium for growth of microorganisms ${ }^{5}$.

Received from Hospital Oswaldo Cruz de Palmas (HOCP), TO, Brazil, and Hospital Geral de Palmas Universidade de Brasilia - UnB, Brazil.

1. Responsible for the Anesthesiology Department of HOCP, Tocantins

2. PhD; Professor of the Genetics and Morphology Department, Instituto de Biologia of UnB

Submitted on July 06, 2010

Approved on August 16, 2010

Correspondence to:

Dra. Luiza Alves de Castro Arai

404- Sul Alameda -02 QR-07 Lote 35

Plano Diretor Sul

77021-618 - Palmas, TO, Brazil

E-mail: luizaarai@gmail.com
Although soda-lime has a bactericidal effect, besides its cytolytic effect ${ }^{5}$, when there is direct contact between the microorganism and the soda-lime granule, experimental studies have reported survival of Pseudomonas aeruginosa, for 18 hours, and Mycobacterium tuberculosis, for 48 hours, in a soda-lime solution ${ }^{6}$, and that those microorganisms crossed the soda-lime-containing canister.

In this ideal culture medium (heat and humidity) for microorganisms in the respiratory circular system of the anesthetic device, Gram-negative bacteria such as Flavobacterium and Pseudomonas ${ }^{7}$ have been isolated. Also, a case of transmission of hepatitis $\mathrm{C}$, whose culprit was most likely the reutilization of the circular circuit ${ }^{8}$ has been reported, as well as other studies demonstrating the growth of several microorganisms in the circular system of the anesthesia equipment $5,7,9-13$. Currently, several steps have been used to resolve the contamination and possibility of cross transmission such as disinfection and sterilization of corrugated tubings, sterilization of tubings, use of non-reusable circuits, and the use of bacterial filters in the circuit.

Through bacteriologic tests of the material from the inside of the expiratory branch of the valvular circuit, after prior disinfection for 30 minutes with $2 \%$ glutaraldehyde, bacterial growth was observed despite the disinfection routine used ${ }^{9}$. In another study, investigators used samples from the expiratory and inspiratory branches of the anesthesia circuit, which were previously cleaned with non-sterile soap and water and disinfected with $1 \%$ sodium hypochlorite, dried with compressed air, and stored without packing. Bacterial growth was observed in all samples. In the so-called clean tracheas, bacterial growth was observed in $35.5 \%$ of the de samples, while in the group of tracheas that had been used bacterial growth was observed in $40 \%$ of the samples. In the sample of the 
interior of the inspiratory branch, growth of two Gram-negative bacteria that cause pulmonary infection, besides other from the saprophytic flora of the human skin was observed ${ }^{10}$. The objective of the present study was to evaluate the contamination of reprocessed tubings and non-reprocessed parts of anesthesia circuits.

\section{METHODS}

After approval by the study nucleus and the General Board of the Hospital Geral de Palmas and Hospital Oswaldo Cruz de Palmas, TO, Brazil, 56 samples were collected from Takaoka, Dräger, and Intermédica anesthesia equipment: 25 samples from Takaoka, 20 samples from Dräger, and 11 samples from Intermédica anesthesia equipment. Samples were collected before each anesthesia and they were divided in groups according to collection sites: inspiratory branch, expiratory branch, canister, collector jar, and soda-lime (for each sample, three granules of soda-limes were collected).

Collection was performed with a swab with Stuart medium, a transport and conservation culture medium, and streaked in culture media for growth and isolation, i.e., Agar blood, Mac Conkey, Mannitol, and Sabouraud.

Initially, the person responsible for the operating room was asked whether tracheas of the anesthesia circuits had been changed; if affirmative, samples were collected.

Samples were collected using a swab with a transport medium, from within the inspiratory and expiratory branches, from their proximal and distal portions, with circular movements in their internal surface. Material was also collected from the internal walls of the canister before anesthesia.

Collections were performed in the circulatory circuits of Dräger, Intermédica, and Takaoka anesthesia equipment.

In the Intermédica anesthesia equipment, shortly after the canister in the circular circuit, there is a recipient used to drain (collector jar) the liquid accumulated during surgery.

In all cases, soda-lime granules were collected before anesthesia; therefore, for each anesthesia, there were at least four samples, and when the Intermédica was used, five samples.

Samples were collected with a swab containing a transport media, so samples remained viable; although it is not a nutritive medium, the Stuart medium, a semi-solid medium containing thiglycolate, glycerol phosphate, and sodium chloride, was chosen since it preserves the viability of most pathogens.

The routine of washing corrugated tracheas and how employees cleaned them was followed-up. It was observed that after each anesthesia, corrugated tracheas were collected and sent to the surgical instrument cleaning service. There, they were washed on tap water and placed in a solution of $1 \%$ sodium hypochlorite for 30 minutes. After this procedure, those corrugated tracheas were washed in running water, dried with compressed air, and packed in non-sterile surgical grade paper and sent along with sterile material to be stored. After some time, when approximately $50 \%$ of samples were collected in the Hospital Geral de Palmas, by determination of the $\mathrm{CClH}$, there was a change in protocol, and $2 \%$ glutaraldehyde ${ }^{17}$ was used in place of the hypochlorite.

In some occasions, it was observed that tracheas in the anesthesia equipment were not changed, but employees still confirmed they were changed.

In Hospital Oswaldo Cruz, a change in protocol according to the $\mathrm{CClH}$ was also done. However, tracheas were sterilized after removal of dirty material; this change in protocol was done after approximately $80 \%$ of samples had been collected.

In those hospitals, an attempt to standardize the soda-lime was made; it would only be changed after a standard retention of $\mathrm{CO}_{2}$, according to capnography had been achieved ${ }^{16}$; however, anesthesiologists' staff change all the time, and some of them ordered the change of soda-lime whenever its color changed from white to purple, while others order its change whenever their shift began. It was observed that, in the majority of samples, it was replaced whenever its color changed, with a mean time of three days. In three cases, the soda-lime was changed after, approximately, 15 days. And in some cases, the change in soda-lime was not recorded.

In one of the hospitals cleaning of the canister was standardized. It was washed with water and soap, disinfected with an alcohol solution and/or with sodium hypochlorite; in the other hospital the soda-lime was changed, but the canister was not cleaned.

With a total of 235 samples, which were streaked in culture media for Gram-positive and Gram-negative bacteria and fungus, a total of 705 cultures were performed. Of those, only the cultures of soda-lime did not show any growth.

During collection, it was evaluated whether the samples did not touch any other part of the anesthesia equipment to avoid false-positive results.

It was observed that anesthetic procedures lasted a mean of two hours and thirty minutes. At the end of the procedure, the circuits were changed and the external part of the equipment was disinfected with $70 \%$ alcohol. It was attempted to establish a mean time between the use of the equipment and a new collection; however, due to the rotation of anesthesiologists and the variety in anesthetic techniques used it was not possible. Therefore, the time among collections, the reuse of the equipment, and a new collection varied.

The software Exce ${ }^{\circledR}$ for Windows ${ }^{\circledR}$ was used for processing the data. The software SPSS ${ }^{\circledR}$ (Statistic Package for the Social Sciences, Chicago, IL, USA) version 13 for Windows ${ }^{\circledR}$ was used for all statistical analysis.

\section{RESULTS}

Samples were collected from 56 anesthetic procedures. Forty-five of those samples were collected from the inspiratory and expiratory branches of the trachea, canister, and sodalime from Takaoka and Dräger anesthesia equipment.

Eleven samples were collected from the collector jar, a drain of the circular circuit, beside the sites already mentioned, from the Intermédica equipment. 
Table I - Results of Cultures of the Samples from the Inspiratory Branches in Anesthetic Procedures

\begin{tabular}{lll}
\hline Microorganism & \multicolumn{2}{l}{ Before } \\
\cline { 2 - 3 } & $\mathrm{n}$ & $\%$ \\
\hline Candida sp & 4 & 7.1 \\
Dermatophytus sp. & 5 & 8.9 \\
Penicillium sp. & 5 & 8.9 \\
Other fungus & 2 & 3.6 \\
S. saprophyticus & 4 & 5.4 \\
S. aureus & 1 & 1.8 \\
No growth & 35 & 64.3 \\
Total & 56 & 100 \\
\hline
\end{tabular}

Table II - Results of Cultures of Samples from the Expiratory Branches in Anesthetic Procedures

\begin{tabular}{lll}
\hline Microorganism & Before \\
\cline { 2 - 3 } & $\mathrm{N}$ & $\%$ \\
\hline Candida $s p$. & 7 & 12.5 \\
Dermatophytus $s p$. & 6 & 10.7 \\
Penicillium $s p$. & 1 & 1.8 \\
Aspergillum $s p$. & 1 & 1.8 \\
Other fungus & 2 & 3.6 \\
S. aureus & 2 & 3.6 \\
S. epidermidis & 1 & 1.8 \\
S. saprophyticus & 2 & 3.6 \\
No growth & 34 & 60.7 \\
Total & 56 & 100 \\
\hline
\end{tabular}

Soda-lime: Growth of fungus or Gram-positive and Gramnegative bacteria was not observed in all cultures of 56 samples of soda-lime granules.

Inspiratory Branch: Table I shows the results from the samples of this site. In 19 samples (33.9\%) collected before the procedure, the presence of at least one microorganism was demonstrated. Besides, more than one microorganism was detected in two of those samples (3.6\%), Staphylococcus aureus, in one of the cases, and Staphylococcus saprophyticus, in the other. In four samples, growth of $S$. saprophyticus was observed, while in one sample, the growth of $S$. aureus was observed. Regarding fungal growth, it was positive in 16 samples with the growth of Candida sp., Penicillium sp., and Dermatophytus sp.

Expiratory Branch: Results of the samples are shown in Table II. Twenty-two samples (39.3\%) collected before the procedure showed growth of microorganisms. More than one organism was not detected in any of the samples. In five samples, the growth of S. aureus, S. saprophyticus, and Staphylococcus epidermidis was observed while seventeen samples showed growth of fungus, Candida sp., Penicillium sp., Dermatophytus sp., and Aspergillus sp.

Canister: Fourteen samples (25\%) collected before the procedure were positive (Table III) with growth of Candida sp., Penicillium sp., Dermatophytus sp., Aspergillus sp., and Fusarium $s p$. Growth of more than one microorganism was not observed.
Table III - Results of Cultures from Canisters in Anesthetic Procedures

\begin{tabular}{lll}
\hline Microorganism & \multicolumn{2}{l}{ Before } \\
\cline { 2 - 3 } & $\mathrm{n}$ & $\%$ \\
\hline Candida sp. & 6 & 10.7 \\
Dermatophytus sp. & 3 & 5.4 \\
Penicillium $s p$. & 2 & 3.6 \\
Aspergillum $s p$. & 1 & 1.8 \\
Fusarium $s p$. & 1 & 1.8 \\
No growth & 41 & 76.7 \\
Total & 56 & 100 \\
\hline
\end{tabular}

Table IV - Results of Cultures form Collecting Jars

\begin{tabular}{lll}
\hline Microorganism & $\mathrm{n}$ & $\%$ \\
\hline Candida sp. & 1 & 9 \\
A. baumannii & 1 & 9 \\
S. saprophyticus & 1 & 9 \\
S. epidermidis & 1 & 9 \\
Dermatophytus sp. & 1 & 9 \\
No growth & 6 & 55 \\
Total & 11 & 100 \\
\hline
\end{tabular}

Collector jar: Five samples were positive (45\%). In two anesthetic procedures, more than one organism was observed, S. saprophyticus, in one of the cases (9.1\%), and a Gram-negative bacterium, Acinetobacter baumannii, in the other $(9.1 \%)$. In another culture, growth of S. saprophyticus, as well as $S$. epidermidis, was observed. In two samples, the growth of two types of fungus was observed in fungal-specific media: Candida sp. and Dermatophytus sp. (Table IV).

\section{DISCUSSION}

Since the antimicrobial activity of glutaraldehyde depends on the conditions of use, such as dilution, contents of organic material ${ }^{17}$, and inadequate use it can lead to the development of a biofilm, a microbial mass containing cell and extracellular material on the surface of objects immersed in liquids (including blood) ${ }^{17}$. Similarly, aqueous chloride solutions are bactericidal with good germicide action, although spore-forming microorganisms are 10 to 1000 times more resistant to chloride than vegetative bacteria, and organic material and alkaline detergents can reduce the efficacy of chloride compounds. Chloride compounds are indicated for medium level disinfection of articles and surfaces as well as decontamination of surfaces ${ }^{17}$. Therefore, removal of organic material and any dirty matter is necessary for the efficacy of those compounds. 
It was observed that initially corrugated tubes were washed with water and soap and placed in $1 \%$ hypochlorite or $2 \%$ glutaraldehyde solution for 30 minutes, and later washed on tap not sterile water, and dried with compressed air. When this non-sterile air from a non-filtered humid system reaches the internal surface of those tubings, they are actually placing new microorganisms in the inspiratory and expiratory branches.

When the compressed air jet reaches the internal surfaces of the inspiratory and expiratory branches of the circular circuit of the equipment, in sites with dirt or biofilm residues, there is the possibility that the compressed air jet will remove the dirt spot and spread it in the interior of the tube therefore repopulating a greater area on the internal lumen of the tubing with still viable microorganisms due to the biofilm.

Since the compressed air jet, that is humid, does not have a bacterial or fluid filter, at the moment those corrugated tubes, dried, in theory, are packed in surgical-grade paper they are still humid due to the compressed air used with a fine layer of fluid. At this moment, a proper environment for the growth of microorganisms was created.

In processed corrugated tubes, called cleaned, we obtained cultures with growth of Candida sp., Dermatophytus sp., Aspergillus sp., and Penicillium sp., as well as the growth of bacteria, such as $S$. aureus, $S$. epidermidis, and $S$. saprophyticus.

Even after being reprocessed, inspiratory and expiratory tubings showed a high index of contamination ${ }^{4-6,9-13,28,19}$, suggesting that the way reprocessing is being performed it is not effective and it did not achieve its objective.

Besides, there are parts of the respiratory circuit of the anesthesia equipment that are not cleaned between anesthesias, such as the soda-lime canister, which, most times, is changed whenever the soda-lime is changed, without prior cleaning of the canister, after several anesthetic procedures.

Directional valves, pop off valves, and reservoir balloons are also part of the anesthesia equipment through which gases enter and leave the patient during mechanical ventilation; those gases are hot and humid, may it be by the process of respiration or release of heat and water from soda-lime during absorption of expired $\mathrm{CO} 2$. This causes accumulation of liquid throughout the respiratory circuit, therefore creating a proper environment for the growth of microorganisms not only in the corrugated tubes but also in other places increasing the possibility of crossed-contamination ${ }^{6-8,11-13}$.

Although in the present study soda-lime cultures did not show growth of microorganisms, there are studies such as those of Langevin who reported the survival of $M$. tuberculosis for more than 48 hours in a highly alkaline medium, and the potential for its spread through the respiratory circuit of the anesthesia equipment 6,19 .
In the cultures of the canister only the growth of viable fungus was observed, despite the alkaline medium it was not regularly washed. We obtained positive culture for Aspergillus $s p$., which can cause pulmonary infection 20 .

Similar to Murphy et al. ${ }^{13}$, that observed contamination in several sites of the respiratory circuit of the anesthesia equipment, in the present study contamination was also observed. In the study conducted on the viability of bacteria after passing through the circular circuit of the anesthesia equipment, they recommended recommended the change of disposable parts and sterilization of all other parts of the circuit.

We questioned whether other parts of the respiratory circular circuit of the anesthesia equipment from which samples were not collected could show a high degree of contamination.

The high index of contamination in the parts of the respiratory circuit of the anesthesia equipment that were analyzed shows that reprocessing is ineffective in disinfecting. However, even if those parts had been sterilized the whole process becomes invalid when parts of the same circuit are not cleaned between each anesthetic procedure, generating the possibility of crossed contamination among patients 6,8 .

In a group of 520 patients undergoing inhalational general anesthesia the efficacy of low-resistance 0.22 -micron bacterial filters in the prevention of postoperative pneumonia ${ }^{14}$ was evaluated. A difference in the development of pneumonia between the group that used the filter and the group that did not use the filter was not observed. Those results suggest that the use of bacterial filters does not have any influence on the incidence of postoperative pneumonia.

In a study to evaluate the efficacy of cleaning the anesthesia equipment to determine whether the use of bacterial filters is needed, three groups of patients, one with symptoms of respiratory tract disease, one with secretions in the respiratory tract, and the last one with chronic bronchitis, were evaluated ${ }^{15}$. Out of 550 cultures performed before and after anesthesia only five cultures were positive for non-pathogenic bacteria, indicating that colonization of the equipment is low and it is controlled by adequate cleaning and sterilization after the use not justifying the use of bacterial filters in anesthesia equipment.

Although the corrugated tracheas of the circular system underwent disinfection with $1 \%$ hypochlorite or $2 \%$ glutaraldehyde before each anesthetic procedure, culture of the samples from their internal walls showed the presence of viable microorganisms.

Under the conditions of the present study, one can conclude that the circular systems of anesthesia equipment can show an elevated degree of contamination by pathogenic microorganisms that can lead to cross infection. Only sterilization accompanied by mechanical cleaning and high-level disinfection of non-sterilizable components can guarantee their safe reutilization. 
Mycobacterium tuberculosis through the anesthesia breathing circuit, Chest, 1999; 115:1107-1114.

07. Body SC, Philip JH - Gram-negative rod contamination of an Ohmeda anesthesia machine. Anesthesiology, 2000;92:911.

08. Heinsen A, Bendtsen F, Fomsgaard A - A phylogenetic analysis elucidating a case of patient-to-patient transmission of hepatitis $C$ virus during surgery. J Hosp Infect, 2000;46:309-313.

09. Pinto PS, Romero MN, Bruno Neto A et al. - Contaminação das traqueias do aparelho de anesthesia. Rev Bras Anestesiol, 1999;49(supl 24):95.

10. Stabile Jr SL, Cicareli DD, Momo T et al. - Avaliação da contaminação do circuito respiratório do aparelho de anestesia. Rev Bras Anestesiol, 1998;48:492-500.

11. Leitjen DT, Rejger VS, Mouton RP - Bacterial contamination and the effect of filters in anaesthetic circuits in a simulated patient model. $J$ Hosp Infect, 1992;21:51-60.

12. Harrison GR - The contamination of volatile anaesthetics in an in-circle vaporizer with water during prolonged closed-circle anaesthesia. Anaesthesia, 2000; 55:791-792.

13. Murphy PM, Fitzgeorge RB, Barrett RF - Viability and distribution of bacteria ofter passage through a circle anaesthetic system. Br J Anaesth, 1991;66:300-304.

14. Garibaldi RA, Britt MR, Webster $C$ et al. - Failure of bacterial filters to reduce the incidence of pneumonia after inhalation anesthesia. Anesthesiology, 1981;54:364-368.

15. Ping FC, Oulton JL, Smith JA et al. - Bacterial filters - are they necessary on anaesthetic machine? Can Anaesth Soc J, 1979;26:415-419.

16. Sociedade de Anestesiologia do Estado de São Paulo - Limpeza, desinfecção e esterilização de equipamentos utilizados em anestesia. Disponível em: <http//www.saesp.org.br>.

17. Brasil. Agência Nacional de Vigilância Sanitária - Segurança e equipamentos médico-hospitalares. Bol Inf Tecnovigil, 2004(4).

18. Rathgeber J, Kietzmann D, Mergeryan $\mathrm{H}$ et al. - Prevention of patient bacterial contamination of anaesthesia-circle-systems: a clinical study of the contamination risk and performance of different heat and moisture exchangers with electret filter (HMEF). Eur J Anaesthesiol, 1997; 14:368-373

19. American Association Nurse Anesthetists - Infection Control Guides. Part III - Infection Control Procedures for Anesthesia Equipment.

20. Murray PR, Rosenthal KS, Kobayashi GS et al. - Princípios Básicos da Microbiologia Médica, em: Murray PR, Rosenthal KS, Kobayashi GS et al. - Microbiologia Médica, $4^{\mathrm{a}}$ Ed, Rio de Janeiro, Guanabara Koogan, 2004;5-80.

21. Medeiros EAS - Infecção Hospitalar: Situação Atual e Medidas de Prevenção, em: Salomão R, Pignatari ACC - Guia de Medicina Ambulatorial e Hospitalar de Infectologia. UNIFESP-EPM, Manole, 2004;535-566.

\section{REFERÊNCIAS / REFERENCES}

01. Kits RJ, Vandam LD - Histórico e Objetivos da Prática Anestésica, em: Miller RD - Tratado de Anestesia. $2^{\mathrm{a}}$ ed, São Paulo, Manole, 1999;3-22.

02. Collins VJ - Técnica de Absorção do Dióxido de Carbono, em: Collins VJ - Princípios de Anestesiologia. $2^{\mathrm{a}}$ Ed, Rio de Janeiro, Guanabara Koogan, 1976;218-223.

03. Saraiva RA - Como evitar a formação de substâncias tóxicas durante a absorção de dióxido de carbono pela cal sodada com uso de anestésicos halogenados. Rev Bras Anestesiol, 2004;54:431-437.

04. Pires OC, Lacerda MA, Fonseca NM et al. - Normatização da limpeza do aparelho de anestesia. SBA/Comissão de Normas Técnicas, 2006. Disponível em: http://www.sba.com.br /educacao/par_cntsa. asp. Acesso em 01/09/07.

05. Teuler RC - L'Eficàcia dels circuits anestèsics: un nou sistema d'anestesia. Acadèmia de Ciències Mèdiques i de la Salut de Catalunya i de Baleares.

06. Langevin PB, Rand KH, Layon AJ - The potential for dissemination of

Resumen: Arai LAC, Azevedo RB - Contaminación del Aparato de Anestesia por Agentes Patógenos.

Justificativa y objetivos: Evaluar la contaminación de los aparatos de anestesia a través de recolecciones de 56 muestras para cultivo en el sistema circular del aparato de anestesia, en traqueas previamente reprocesadas por desinfección con hipoclorito al 1\% o glutaraldehido al $2 \%$, después del lavado con jabón y agua no estériles, secadas con chorro de aire comprimido y almacenadas en papel quirúrgico, y en otros locales del circuito respiratorio no reprocesados, antes de los procedimientos anestésicos.

Método: Fueron realizados cultivos de muestras de las traqueas de los ramos inspiratorios, ramos espiratorios, caníster, cal sodada y frasco recolector (dreno), a través de swab con medio Stuart, y sembradas entre los cultivos Agar sangre, Mac Conkey y Sabouraud.

Resultados: En las traqueas reprocesadas de los ramos inspiratorios y espiratorios de los aparatos de anestesia, el nivel de conta- 
minación en algunos sitios fue de hasta un $39,3 \%$, con la presencia de hongos y bacterias, siendo que en algunos casos había más de un microorganismo, un $75 \%$ de la contaminación por hongos y un $25 \%$ de bacterias. Se encontró un cultivo positivo para Candida sp., Dermatophytus sp., Penicillium sp., Aspergillus sp., Staphylococcus aureus, Staphylococcus saprophyticus y Staphylococcus epidermidis. En el caníster, hubo contaminación en un $25 \%$, con el aumento de Candida sp., Penicillium sp., Dermatophytus sp., Aspergillus sp. y Fusarium sp. En el frasco recolector, se observó la contaminación de un $36 \%$ de las muestras analizadas, con un crecimiento de
Candida sp., Dermatofitus sp., S. saprophyticcus y Acinetobacter baumannii. En los cultivos de la cal sodada no hubo crecimiento de microorganismos.

Conclusiones: En todos los puntos analizados, con excepción de la cal sodada, hubo un aumento de los microorganismos, con la posibilidad de contaminación cruzada.

Descriptores: EQUIPO DE ANESTESIA, Sistema respiratório: contaminación; COMPLICACIÓNES: Infección hospitalar. 